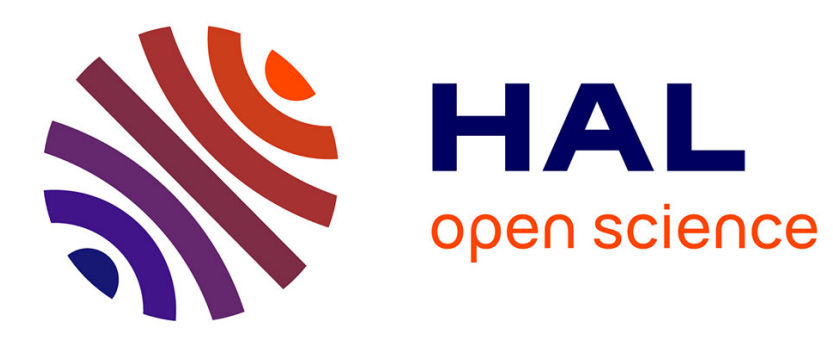

\title{
Matrix metalloproteinase-dependent regulation of extracellular matrix shapes the structure of sexually differentiating mouse gonads
}

Rafal P. Piprek, Malgorzata Kloc, Jacek Z. Kubiak

\section{- To cite this version:}

Rafal P. Piprek, Malgorzata Kloc, Jacek Z. Kubiak. Matrix metalloproteinase-dependent regulation of extracellular matrix shapes the structure of sexually differentiating mouse gonads. Differentiation, 2019, 106, pp.23-34. 10.1016/j.diff.2019.01.006 . hal-02118548

HAL Id: hal-02118548

https://hal-univ-rennes1.archives-ouvertes.fr/hal-02118548

Submitted on 8 Jul 2019

HAL is a multi-disciplinary open access archive for the deposit and dissemination of scientific research documents, whether they are published or not. The documents may come from teaching and research institutions in France or abroad, or from public or private research centers.
L'archive ouverte pluridisciplinaire HAL, est destinée au dépôt et à la diffusion de documents scientifiques de niveau recherche, publiés ou non, émanant des établissements d'enseignement et de recherche français ou étrangers, des laboratoires publics ou privés. 
1 Matrix metalloproteinase-dependent regulation of extracellular matrix

2 shapes the structure of sexually differentiating mouse gonads

3

4

Rafal P. Piprek $^{1 *}$, Malgorzata Kloc ${ }^{2,3,4}$, Jacek Z. Kubiak ${ }^{5,6}$

${ }^{1}$ Department of Comparative Anatomy, Institute of Zoology and Biomedical Research, Jagiellonian University, Krakow, Poland

${ }^{2}$ The Houston Methodist Research Institute, Houston, TX, USA

${ }^{3}$ Department of Surgery, The Houston Methodist Hospital, Houston TX, USA

${ }^{4}$ University of Texas, MD Anderson Cancer Center, Houston TX, USA

${ }^{5}$ Univ Rennes, CNRS, Institute of Genetics and Development of Rennes, UMR 6290, Cell Cycle Group, Faculty of Medicine, F-35000 Rennes, France

${ }^{6}$ Laboratory of Regenerative Medicine and Cell Biology, Military Institute of Hygiene and Epidemiology (WIHE), Warsaw, Poland

Corresponding author:

Rafal P. Piprek

Department of Comparative Anatomy

Institute of Zoology and Biomedical Research

Jagiellonian University

Gronostajowa 9

30-387 Krakow, Poland

Phone: +48126645059

e-mail: rafal.piprek@uj.edu.pl 


\section{Abstract}

The extracellular matrix (ECM) proteins play an important role in the establishment of the sex-dependent structure of developing gonads. The matrix metalloproteinases (MMPs) are the major players in the regulation of ECM. Our hypothesis was that the MMPs-dependent regulation of EMC is crucial for the establishment of the correct, either testis or ovary, structure of developing gonad. We cultured developing mouse gonads in vitro in the presence of the MMPs inhibitors ( $\alpha$-2-macroglobulin, leupeptin, phosphoramidon) or the MMPs activator, APMA (4-aminophenylmercuric acetate). These inhibitors and activator inhibit/activate, to a different degree, matrix metalloproteinases, but the exact mechanism of inhibition/activation remains unknown. We found that the MMP inhibitors increased accumulation of ECM in the developing gonads. The $\alpha$-2-macroglobulin had the weakest, and the phosphoramidon the strongest effect on the ECM and the structure of the gonads. The $\alpha-2-$ macroglobulin caused a slight increase of ECM and did not disrupt the gonad structure. Leupeptin led to the strong accumulation of ECM, resulted in the formation of the structures resembling testis cords in both testes and ovaries, and caused increase of apoptosis and complete loss of germ cells. Phosphoramidon caused the strongest accumulation of ECM, which separated individual cells and completely prevented intercellular adhesion both in the testes and in the ovaries. As a result of abberrant morphology, the sex of the phosphoramidontreated gonads was morphologically unrecognizable. The APMA - the activator of MMP caused ECM loss, which led to the loss of cell adhesion, cell dispersion and an aberrant morphology of the gonads. These results indicate that the ECM accumulation is MMPsdependent and that the correct amount and distribution of ECM during gonad development plays a key role in the formation of the gonad structure.

\section{Highlights:}

- Inhibition of MMPs in developing gonads leads to accumulation of ECM

- Inhibition of MMPs causes decrease of testis-markers expression

- Accumulation of ECM in developing gonads disrupts cell adhesion

- Accumulation of ECM disrupts gonad structure formation

- Activation of MMPs leads to dispersion of gonad cells

Key words: extracellular matrix; gonad differentiation; ovary; testis; metalloproteinases; $\alpha-2$ macroglobulin; leupeptin; phosphoramidon; APMA 


\section{Introduction}

During sexual differentiation of the gonads, the bipotential gonads differentiate into the testis or ovary. Although this processes has been well studied in mice, the molecular and cellular machinery governing the development of testes and ovaries is very complex and still requires further studies. Gonad primordia, termed genital ridges, appear in mice soon before $10.5^{\text {th }}$ day of embryonic life (E10.5) (Hu et al., 2013; reviewed by Piprek et al., 2016). Between stage E10.5 and E12.5, the still undifferentiated gonads initiate the expression of sex-determining genes (Bullejos and Koopman, 2001; Kobayashi et al., 2005). Depending on the genetic sex, the male or female sex-determining pathway prevails and determines the structure and fate of the gonad (Kim et al., 2006; Chassot et al., 2008; reviewed by Piprek, 2009a,b). The first differences in the structure between male and female gonads appear around stage E12.5 (Schmahl et al., 2000; Nel-Themaat et al., 2009; reviewed by Piprek, 2010). A day later, i.e. at E13.5, the gonads are already sexually differentiated, and their sex can be easily distinguished histologically (Nel-Themaat et al., 2009). In the differentiating testes, the somatic cells derived from the coelomic epithelium proliferate leading to the extensive growth of the male gonad (Schmahl et al., 2000). The presumptive Sertoli cells enclose germ cells forming elongated testis cords surrounded by the basement membrane (Svingen and Koopman, 2013). The cells migrating from the adjacent mesonephros give rise to mainly the endothelial cells of the gonad vasculature (Brennan et al., 2002). The subpopulation of the mesonephros-derived cells, and the cells derived from the coelomic epithelium form the interstitium, which separate the testis cords, and thus, shape the testis structure (Tilmann and Capel, 1999; DeFalco et al., 2011). The interstitium contains steroidogenic fetal Leydig cells (FLCs) and abundant extracellular matrix (ECM). The development of the ovary takes a different path. Although the germ cells in developing ovary also become surrounded by the somatic cells (pre-follicular cells) (Albrecht and Eicher, 2001), the elongated cords do not develop. The ovigerous cords are built of many small and irregularly shaped clusters of the somatic and germ cells, known as the germ cell nests, embedded in the ovarian stroma (Lei and Spradling, 2013). Later in development, the ovigerous cords split into ovarian follicles (Pepling and Spradling, 2001; Pepling et al., 2010).

It has been shown that in mouse, rat, cattle, chicken, slider (Trachemys scripta) and the African clawed frog (Xenopus laevis) (Paranko et al., 1983; Yao et al., 2004; Hummitzsch et al., 2013; Piprek et al., 2017a,2018) the ECM plays important role in gonad development. The ECM contains many different proteins including collagens, laminins, fibronectin, and proteoglycans (reviewed by Yue, 2014). The amount and distribution of ECM depends on two 
103 processes: i.) synthesis of the ECM components and their deposition between cells, ii.)

104 degradation of the ECM components by the extracellular matrix enzymes (ECM enzymes).

105 Two main groups of ECM enzymes involved in the ECM formation/degradation are matrix 106 metalloproteinases (MMPs: MMP1 to MMP28) that digest ECM components, and inhibitors 107 of MMPs (TIMPs), which inhibit MMPs (Birkedal-Hansen, 1993; Stamenkovic, 2003; Arpino 108 et al., 2015). We hypothesize that a balance between the formation and degradation of ECM 109 components plays an important role in the regulation of the amount and distribution of ECM.

110 The knowledge on the role of the ECM in gonad development, especially during the 111 sexual differentiation, is very limited. We showed recently that in the mouse, between E11.5 112 and E13.5 (i.e. during the period of sexual differentiation) many genes encoding ECM 113 components and MMPs are expressed differentially in the male and female gonads (Piprek et 114 al. 2018). Considering the high number of ECM enzymes, the machinery of ECM remodeling 115 in developing gonads is probably very complex. Because the structure of the gonads is 116 different between sexes, the ECM has different distribution in the testes and ovaries; 117 presumably the sex-determining pathways (responsible for the gonad fate) also regulate the 118 sex-specific distribution of ECM. Indeed it has been shown that in the mouse, the TIMP3, an 119 enzyme inhibiting MMPs, is upregulated by male sex-determining pathway (Nishino et al., 120 2002). Moreover, gonads develop in the close proximity of the mesonephros. Between these 121 two organs there is the vascular plexus. The vascular plexus disintegrates, and mesonephric 122 cells derived from the disintegrating vascular plexus contribute to the endothelium and 123 interstitium of the gonad, which is crucial for the patterning of testis cords (Coveney et al., 124 2008). The ECM enzymes are probably involved in the disintegration of vascular plexus and 125 thus they facilitate the migration of the mesonephros-derived cells to the gonads. Several 126 studies showed the role of ECM enzymes in kidney development (Ota et al., 1998; Tanney et 127 al., 1998; Lelongt et al., 2005), however, a role of mesonephros in sexual differentiation of 128 gonads remains unknown. It is known that tubular system of mesonephros joins rete testis 129 later in development, however, molecular mechanisms driving this process are obscure 130 (Joseph et al., 2009; Davidson et al., 2018).

131 Because the ECM is differentially patterned in developing testes and ovaries, and the 132 genes encoding ECM components and enzymes responsible for ECM remodeling are 133 differentially expressed, we hypothesized that the ECM and its enzymes are important factors 134 controlling sexual differentiation of the gonads. The aim of this study was to explore how the 135 structure of differentiating mouse testes and ovaries changes upon inhibition or activation of 136 ECM regulating enzymes. Fetal gonads isolated at E11.5, i.e. just before the onset of sexual 
differentiation, were cultured in a medium supplemented with the inhibitors of MMPs $(\alpha-2-$ macroglobulin, leupeptin, or phosphoramidon) or with the activator (APMA, 4aminophenylmercuric acetate) (Table 1). The gonads were analyzed after 3 days in culture using histological techniques, immunohistochemistry and gene expression analysis.

\section{Material and methods}

\subsection{Animals and genotyping}

The gonads were isolated from the $\mathrm{C} 57 \mathrm{bl} / 6$ mouse strain. The study was approved by the I Local Commission for Ethics in Experiments on Animals. The animals were bred and housed in the Animal Facility at the Jagiellonian University (Krakow, Poland). The number of studied animals is presented in Table 1 . Timed matings were performed by placing a male with 2 females overnight. The following morning, females were checked for the presence of the vaginal plug, and the pregnancies were estimated as E0.5 (embryonic day). Females were euthanized by spinal dislocation at 11.5 . The sex of all studied animals was confirmed by genotyping using primers for Sly (Y chromosome) and Xlr (X chromosome) (McFarlane et al., 2013). Primers used for genotyping are listed in Suppl. Table 1. PCR reactions were performed in a final volume of $10 \mu \mathrm{l}$ with primers $(0.5 \mu \mathrm{L}$ each), extracted DNA $(1 \mu \mathrm{L})$, water $(3.5 \mu \mathrm{L})$, and 2X PPP Master Mix (Top-Bio) $(5 \mu \mathrm{L})$ and the following PCR parameters: initial denaturation at $94^{\circ} \mathrm{C}$ for $2 \mathrm{~min}, 35$ cycles at $94^{\circ} \mathrm{C}$ for $30 \mathrm{~s}, 57^{\circ} \mathrm{C}$ for $30 \mathrm{~s}$, and $72^{\circ} \mathrm{C}$ for $30 \mathrm{~s}$, followed by final elongation at $72{ }^{\circ} \mathrm{C}$ for $5 \mathrm{~min}$. PCR products were electrophoresed on $2 \%$ agarose gels containing GelRed (Biotium) and visualized under UV-illumination.

\subsection{In vitro culture}

Gonads were dissected from embryos at E11.5 along with mesonephroi and cultured on agar in DMEM high glucose GlutaMAX (ThermoFisher, 10566) medium supplemented with $10 \%$ fetal bovine serum (FBS, Biomedical Industries, 04-001) and a mixture of antibiotics (penicillin $100 \mathrm{U} / \mathrm{ml}$, streptomycin $100 \mu \mathrm{g} / \mathrm{ml}$, amphotericin B $0.25 \mu \mathrm{g} / \mathrm{ml}$, Biomedical Industries, 03-033). For MMP inhibition, $\alpha$-2-macroglobulin, leupeptin, phosphoramidon were added to the medium at concentration listed in Table 2. To activate MMPs, an activator (APMA, 4-aminophenylmercuric acetate) was added to the medium (Table 2). Inhibitors and the activator were dissolved in DMSO (Sigma, D2650) and added in amount of $1 \mu \mathrm{l} / \mathrm{ml}$ of the medium. Only DMSO $(1 \mu \mathrm{l} / \mathrm{ml})$ was added to the medium in the control. Organs were cultured at the air/medium interface for 3 days at $37^{\circ} \mathrm{C}$ in $5 \% \mathrm{CO}_{2}$. 


\subsection{MMPs modulators}

$\alpha$-2-macroglobulin is an endogenous large plasma protein, synthesized mainly in the liver (Rehman et al., 2013). It has a broad spectrum of action in an organism, including modulation of growth factors activities, regulation of blood coagulation, and functions in developmental process, such as the development of liver in zebrafish (Westwood et al., 2001; Hong and Dawid, 2008). Leupeptin (N-acetyl-L-leucyl-L-leucyl-L-argininal) is a protease inhibitor produced by actinomycetes. It also has a broad spectrum of action, and inhibits numerous enzymes, such as MMPs, serine and threonine proteases, calpain, cathepsin, trypsin, plasmin, papain (Kuramochi et al., 1979). Phosphoramidon derives from the bacterium Streptomyces tanashiensis isolated from the soil in Japan (Kitagishi and Hiromi 1984). It inhibits MMPs and bacterial thermolysin, and regulates endothelins that have a key role in vascular homeostasis (Plumpton et al., 1994; McMahon et al., 1991; Keller et al., 1996). APMA (4-aminophenylmercuric acetate) is an organomercurial compound and thiolblocking reagent, which activates MMPs and collagenase proteolytic enzymes (Rosenfeldt et al., 2005).

\subsection{Gelatin zymography}

Activity of MMPs was studied as previously described (Hibbs et al., 1985). After 3 days of in vitro culture, gonads were lysed for $30 \mathrm{~min}$. at $4^{\circ} \mathrm{C}$ with $20 \mu \mathrm{l}$ of $1 \% \mathrm{NP}-40$ and 5mM EDTA. Lysates were mixed with Zymogram sample buffer (ZymoResearch) with 2\% SDS and 10\% glycerol and subjected to electrophoresis on a 10\% SDS-polyacrylamid gel containing $1 \mathrm{mg} / \mathrm{mL}$ gelatin (Sigma) in the absence of any reducing agent, at room temperature. The gel was washed $4 \mathrm{x}$ in the washing buffer $(50 \mathrm{mM}$ Tris- $\mathrm{HCl}, 5 \mathrm{mM} \mathrm{CaCl} 2,5$ $\mu \mathrm{M} \mathrm{ZnCl}_{2}, 0.02 \% \mathrm{NaN}_{3}$ and $2.5 \%$ Triton $\mathrm{X}-100$ ). The gel was stained with Coomassie

Brilliant blue R-250, washed in Coomassie washing solution, dried, and documented.

\subsection{RNA isolation and Real-Time Quantitative PCR ( $q P C R)$}

After 3 days of culture the gonads were pooled accordingly to the genetic sex. Total RNA was isolated using Trizol and further purified with RNeasy Mini kit per manufacturer's instructions (Qiagen, Valencia, CA). Total RNA in RNase-free water was frozen at $-80^{\circ} \mathrm{C}$ and then used for multigene qPCR analysis. $50 \mathrm{ng}$ RNA of each sample was reverse-transcribed into cDNA using random primers and SuperScript III Reverse Transcriptase (Invitrogen, 18080044) following manufacturer's instructions. A list of primers is presented in Suppl.

Table 1. The RT-qPCR procedure was performed in $5 \mu$ reactions using SYBR Green Master 
Mix (Life Technologies, 4312704) on a 7500 Fast Real-Time PCR System (Applied

Biosystems) with universal cycling parameters and analyzed as previously described (Svingen et al., 2009). Data were collected as raw $C_{\mathrm{T}}$ values and analyzed using the $2^{-\Delta \Delta \mathrm{CT}}$ method. Beta-actin $(A c t b)$ was used as a reference gene. Gene expression was normalized on an arbitrary scale with $A c t b$ as 1.0. Statistical analysis was performed using the nonparametric ANOVA Kruskal-Wallis test followed by the Tukey's test. Statistica 7.0 software was used

211 for the analyses.

\subsection{Histology and Immunohistochemistry}

Freshly isolated gonads and gonad after 3 days of in vitro culture, were rinsed in PBS and fixed in Bouin's solution, dehydrated and embedded in paraffin (Paraplast, Sigma, P3683). Histological staining was performed according to Debreuill's trichromatic method as previously described (Kiernan, 1990; Piprek et al., 2017b). For immunochemistry, heatinduced epitope retrieval was conducted in sodium citrate buffer $(10 \mathrm{mM}$ sodium citrate, $0.05 \%$ Tween-20, $\mathrm{pH} 6$ ) at $95^{\circ} \mathrm{C}$ for 20 minutes. Subsequently, the sections were blocked with $3 \% \mathrm{H}_{2} \mathrm{O}_{2}$ and $10 \%$ goat serum (Sigma, G9023). Sections were incubated with primary antibodies (all rabbit polyclonal: anti-AMH, Santa Cruz Biotechnology, sc-166752; anticollagen I, Abcam, ab34710; anti-laminin, Abcam, ab11575; anti-cleaved caspase 3, Assay BioTech, L0104) at $4^{\circ} \mathrm{C}$ overnight, and with UltraVision Quanto Detection System (TL-125QHD). Mayer's hematoxylin was used as a counterstain. Sections were examined under Nikon Eclipse E600 microscope. The germ cells and somatic cells were identified by the size and morphological features. The germ cells were larger than the somatic cells, and had a large, round and pale nuclei. The somatic cells were smaller than the germ cells and had small and dark nuclei. The apoptotic cells were identified by the presence of small, dark, pyknotic nuclei with a highly condensed chromatin, and by caspase 3 immunostaining.

\subsection{Quantification of apoptotic cells}

The number of (caspase 3-positive) apoptotic cells was calculated within the 10,000 $\mu \mathrm{m}^{2}$ area in 5 cross sections from each gonad using ImageJ software. The number of apoptotic cells in gonads cultured in medium supplemented with MMP inhibitors and 
3. Results and discussion

3.1. Activity of MMPs in the gonads after incubation in the presence of inhibitors and activator

Zymography analyses showed that $\alpha$-2-macroglobulin, leupeptin and phosphoramidon inhibited MMP2, MMP3 and MMP9 in the gonads after 3 days of in vitro culture (Fig. 1). Phosphoramidon inhibited MMP2, MMP3 and MMP9 to the higher degree than a $\alpha-2-$ macroglobulin and leupeptin did. As expected, APMA activated MMP2, MMP3 and MMP9 (Fig. 1). The results of these experiments are summarized in Table 3.

\subsection{Development of gonads under control in vitro conditions}

The histology of the freshly isolated XY and XX gonads, before the start of the in vitro culture, was identical (Fig. 2A,C).

\subsubsection{XY gonads}

After three days of in vitro culture the XY gonads contained cell clusters (Fig. 3A). These clusters, which are the early testis cords, contained the germ cells with large, round nuclei, surrounded by AMH (anti-müllerian hormone) positive pre-Sertoli cells with the small nuclei (Fig. 3C). The clusters of pre-Sertoli/germ cells were enclosed by the basement membrane. The space (interstitium) between the cords was filled with the thin layers of ECM (Fig. 3E). Immunostaining showed that this interstitial ECM contained collagen I and laminin (Fig. 3E,G). Only singular apoptotic cells were present (Fig. 3I). The overall structure of the testis was similar to the structure of physiologically developing testes of the same age (Fig. 2B).

\subsubsection{XX gonads}

The XX gonad after 3 days of in vitro culture had poorly defined clusters of somatic and germ cells (Fig. 5A), which were separated by a small amount of ECM containing collagen I and laminin (Fig. 5C,E). Only singular apoptotic cells were present (Fig. 5G). The overall structure of the ovary was similar to the physiologically developing ovaries of the same age (Fig. 2D).

\subsection{The effect of $\alpha$-2-macroglobulin inhibitor on ECM and gonad structure}

\subsubsection{XY gonads}

The structure of XY gonads cultured for 3 days in the medium supplemented with $\alpha-2$ macroglobulin, which inhibits MMPs, was similar to the control gonad cultured in the absence of inhibitor. Both contained well defined testis cords containing germ and somatic cells (Fig. 
3B). The only noticeable difference was the higher amount of ECM around the cords and the stronger collagen I and laminin immunostaining in the gonad cultured in the presence of inhibitor (Fig. 3F,H). This indicates that $\alpha$-2-macroglobulin, which inhibits MMPs, inhibited disintegration of ECM. The AMH immunostaining showed the presence of solid, well differentiated clusters of pre-Sertoli cells in the testis cords both in control and in cultured gonads (Fig. 3D). Singular apoptotic (caspase 3-positive) cells were observed, indicating cell death (Fig. 3J, Table 4).

\subsubsection{XX gonads}

The overall structure of the XX gonads after three days of culture in the medium supplemented with $\alpha$-2-macroglobulin was similar to the control. However, in the inhibitor treated gonads, the amount of ECM was higher (Fig. 5B). The streams of ECM separated clusters of somatic/germ cells (Fig. 5D,F).

These results indicate that the in vitro exposure of gonads to the $\alpha$-2-macroglobulin inhibitor causes only moderate increase of ECM and does not affect the structure of developing XX or XY gonads.

\subsection{Leupeptin increases ECM content and changes gonad structure}

\subsubsection{XY gonads}

Our zymography analysis showed that leupeptin had a stronger inhibitory effect on MMPs than $\alpha$-2-macroglobulin (Fig. 1). Accordingly, we found that the gonad cultured in the medium supplemented with leupeptin had higher content of ECM than the gonads cultured with $\alpha$-2-macroglobulin (Fig. 4A). After three days of culture in the medium supplemented with leupeptin, XY gonads contained strong accumulations of ECM components, i.e. collagen I and laminin (Fig. 4E,G). AMH immunostaining showed that the integrity of testis cords was compromised; the clusters of AMH-positive cells were much looser than in control (Fig. 4C). Such testis cords were surrounded by a high accumulation of ECM. The germ cells were absent, indicating that leupeptin led to the loss of germ cells. Occasionally apoptotic cells were observed, indicating enhanced cell death (Fig. 4I, Table 4).

\subsubsection{XX gonads}

The XX gonads cultured in the medium with leupeptin, similar to the XY gonads, had higher content of ECM (Fig. 6A,C,E) and lacked the germ cells.

\subsection{The phosphoramidon causes very high accumulation of ECM and changes the structure of $X Y$ and $X X$ gonads}


The structure of the gonads cultured for three days in the medium supplemented with phosphoramidon had a very high accumulation of ECM components collagen I and laminin (Fig. 4B,D,F,H, 6B,D,F). The ECM was so abundant that it separated all cells preventing intercellular adhesion. As a result, the clusters of cells, such as testis cords, were absent, and AMH-positive cells were dispersed (Fig. 4D). The germ cells were absent and the apoptotic cells were present and in XX and XY gonads (Fig. 4B,I, 6B,H). Among all used MMPs inhibitors, the number of apoptotic cells in the phosphoramidon supplemented medium was the highest (Table 4). Because of theprofound changes in the gonad structure, the gonad sex was morphologically unrecognizable. The XY and XX had the same structure with the dispersed cells embedded in ECM. This indicated that phosphoramidon had very strong inhibitory effect on MMPs, which resulted in excessive accumulation of ECM. This in turn caused complete disruption of the gonad structure and the loss of the germ cells.

It has been shown that the proper cell adhesion is important for the germ cell survival in mouse gonads (Nagano et al., 2000; Luaces et al., 2014). This explains why the excessive accumulation of ECM around the cells, which prevents cell adhesion caused germ cell loss in the gonads cultured in the presence of MMPs inhibitors.

Although, the phosphoramidon was described previously as a weak MMP inhibitor (Kitagishi and Hiromi, 1984; Matsumura et al., 1990), in our experimental system phosphoramidon had the strongest inhibitory effect on MMPs in developing gonads. The strong correlation between the zymography-measured anti-MMP activity of used inhibitors, ECM content, and the changes in the gonads structure, described here, argues for the important role of MMPs and ECM in the process of gonad development and germ cell survival, and thus for the future fecundity of the individual.

Mazaud and coauthors (2005) showed that the rat ovaries cultured in vitro in the presence of $\alpha$-2-macroglobulin or phosphoramidon had only sporadic ovarian follicles, which indicated a partial inhibition of folliculogenesis. However, a culture of ovaries with leupeptin led to a complete absence of ovarian follicles (ibid). In our experimental system the leupeptin had much lower impact on gonad development than the phosphoramidon. This points to the profound differences between the processes of sexual differentiation of gonads and the 
The structure of the gonads after three days of culture in the medium supplemented with APMA was drastically altered (Fig. 7A-C). XY and XX gonads were morphologically undistinguishable. All somatic cells were widely dispersed within the gonad, did not adhere one to another, and only very low amount of ECM was present, and the germ cells were either absent or morphologically unrecognizable.

\subsection{Modifications of gene expression pattern by MMPs modulators}

To identify molecular effects of the MMPs modulators, we studied the expression of marker gene for the female germ cells (Oct4), testis specific Sertoli cells (Sox9, Amh), ovary specific follicular cells ( $F s t$ ) The actin $\beta$ encoding gene (Actb), was used as a control (Fig. 8). Inhibitors of MMPs caused a significant decrease of Oct4 expression in both XY and XX gonads. The APMA activator of MMPs, caused a slight increase in Oct4 expression (Fig. 8). A decrease of Oct4 expression likely reflected the observed germ cell loss.

The Sertoli cell marker Sox9 had decreased expression in XY gonads cultured with MMP inhibitors. Sox9 expression was almost completely lost in the gonads treated with MMP activator APMA (Fig. 8). The expression of Amh, another Sertoli cells marker, was slightly lower in XY gonads cultured with MMPs inhibitors, and was almost completely lost in gonads treated with MMP activator. These results indicate that disregulation (increase or decrease) of the amount) of ECM content disrupts differentiation of Sertoli cells. This, in turn, implies that a proper content and distribution of ECM may be critical for the expression of genes directing sex determination and differentiation of Sertoli cells.

Fst, a marker of the developing ovary, remained unchanged (low in XY gonads and elevated in XX gonads) in the presence of MMP inhibitors and slightly downregulated in the presence of MMP activator (Fig. 8). This indicates that the expression of ovarian markers is not affected by the changes in ECM. It is possible that the changes in ECM and cell adhesion are less important for ovarian than testis development.

The gene expression analysis showed that MMP inhibition or activation did not impaired sex determination in the gonads; the ovarian marker $(F s t)$ was not upregulated in the XY gonads, and Sertoli cells markers (Sox9, Amh) were not upregulated in the XX gonads (Fig. 8). Thus, no sex reversal was detected. Importantly, the Actb gene (used as a control) was expressed at the constant level in all analyzed gonads, which indicated that the observed changes in the expression of markers were not caused by the in vitro culturing conditions. 


\section{Conclusion}

We showed that the modulators, both the inhibitors and the activator, of MMPs trigger important changes in the structure of sexually differentiating developing mouse gonads (Table 3). 1. MMPs inhibitors causes accumulation of ECM, which drives cells dispersion and disappearance of testis cords. 2. MMPs activator APMA causes ECM loss and a complete disruption of the gonad structure. Thus, both the excessive accumulation of ECM and its decrease or loss leads to a dramatic impairment of the tissue architecture in developing gonads. In addition, leupeptin and phosphoramidon led to the enhanced apoptosis and the loss of germ cells, and thus lowered expression of germ cell marker Oct4. APMA decreased the expression level of Sertoli cell markers Sox9, Amh, which indicated disruption of Sertoli cell integrity. Thus, we postulate that the ECM amount, which depends on a balanced synthesis and degradation of its components, is critical for the establishment of the proper structure of the gonads, and that MMPs play a crucial role in this process.

Acknowledgments

The study was conducted within the project financed by the Polish National Science Centre (NCN) assigned on the basis of the decision number DEC-2013/11/D/NZ3/00184.

\section{References}

Albrecht, K.H., Eicher, E.M. 2001. Evidence that Sry is expressed in pre-Sertoli cells and Sertoli and granulosa cells have a common precursor. Dev. Biol. 240, 92-107.

Arpino, V., Brock, M., Gill, S.E., 2015. The role of TIMPs in regulation of extracellular matrix proteolysis. Matrix Biol. 44-46, 247-254.

Birkedal-Hansen, H., 1993. Role of matrix metalloproteinases in human periodontal diseases. J. Periodontol. 64, 474-484.

Brennan, J., Karl, J., Capel, B., 2002. Divergent vascular mechanisms downstream of Sry establish the arterial system in the XY gonad. Dev. Biol. 244, 418-428.

Bullejos, M., Koopman P., 2001. Spatially dynamic expression of Sry in mouse genital ridges. Dev. Dyn. 221, 201-205.

Cawston, T.E., Mercer, E., 1986. Preferential binding of collagenase to alpha 2-macroglobulin in the presence of the tissue inhibitor of metalloproteinases. FEBS Lett. 209, 9-12.

Chassot A.A., Ranc F., Gregoire E.P., Roepers-Gajadien H.L., Taketo M.M., Camerino G., de 410 Rooij D.G., Schedl A., Chaboissier M.C., 2008. Activation of beta-catenin signaling by

411 Rspo1 controls differentiation of the mammalian ovary. Hum. Mol. Genet. 17, 1264-77. 
412

413

414

415

416

417

418

419

420

421

422

423

424

425

426

427

428

429

430

431

432

433

434

435

436

437

438

439

440

441

442

443

444

445

446

447

448

449

450

451

452

453

454

455

456

457

458

459

460

Coveney, D., Cool, J., Oliver, T., Capel, B., 2008. Four-dimensional analysis of vascularization during primary development of an organ, the gonad. Proc. Natl. Acad. Sci. U. S. A. $105,7212-7217$.

Davidson, A.J., Lewis, P., Przepiorski, A., Sander, V., 2018. Turning mesoderm into kidney. Semin. Cell Dev. Biol. S1084-9521, 30417-2.

DeFalco, T., Takahashi, S., Capel, B., 2011. Two distinct origins for Leydig cell progenitors in the fetal testis. Dev. Biol. 352, 14-26.

Galazka, G., Windsor, L.J., Birkedal-Hansen, H., Engler, J.A., 1996. APMA (4aminophenylmercuric acetate) activation of stromelysin-1 involves protein interactions in addition to those with cysteine- 75 in the propeptide. Biochemistry $35,11221-7$.

Hibbs, M.S., Hasty, K.A., Seyer, J.M., Kang, A.H., Mainardi, C.L., 1985. Biochemical and immunological characterization of the secreted forms of human neutrophil gelatinase. J. Biol. Chem. 260, 2493-500.

Hong, S.K., Dawid, I.B., 2008. Alpha2 macroglobulin-like is essential for liver development in zebrafish. PLoS One 3(11), e3736.

Hu, Y.C., Okumura, L.M., Page, D. C., 2013. Gata4 is required for formation of the genital ridge in mice. PLoS Genet 9, e1003629.

Hummitzsch, K., Irving-Rodgers, H.F., Hatzirodos, N., et al., 2013. A new model of development of the mammalian ovary and follicles. PLoS One 8(2), e55578.

Joseph, A., Yao, H., Hinton, B.T., 2009. Development and morphogenesis of the Wolffian/epididymal duct, more twists and turns. Dev. Biol. 325, 6-14.

Keller, P.M., Lee, C.P., Fenwick, A.E., Atkinson, S.T., Elliott, J.D., DeWolf, W.E. Jr., 1996. Endothelin-converting enzyme: substrate specificity and inhibition by novel analogs of phosphoramidon. Biochem. Biophys. Res. Commun. 223, 372-8.

Kiernan, J.A., 1990. Histological and Histochemical Methods: Theory and Practice. 2nd ed. Oxford, New York, Seoul, Tokyo: Pergamon Press.

Kim Y., Kobayashi A., Sekido R., DiNapoli L., Brennan J., Chaboissier M.C., Poulat F., Behringer R.R., Lovell-Badge R., Capel B., 2006. Fgf9 and Wnt4 act as antagonistic signals to regulate mammalian sex determination. PLoS Biol. 4(6), e187.

Kitagishi, K., Hiromi, K., 1984. Binding between thermolysin and its specific inhibitor, phosphoramidon. J. Biochem. 95, 529-34.

Kobayashi A., Chang H., Chaboissier M.C., Schedl A., Behringer R.R., 2005. Sox9 in testis determination. Ann. N. Y. Acad. Sci. 1061, 9-17. 
Kuramochi, H., Nakata, H., Ishii, S., 1979. Mechanism of association of a specific aldehyde inhibitor, leupeptin, with bovine trypsin. J. Biochem. 86, 1403-10.

Lei L., Spradling, A.C., 2013. Mouse primordial germ cells produce cysts that partially fragment prior to meiosis. Development 140, 2075-2081.

Lelongt, B., Bengatta, S., Ronco, P., 2005. Role of matrix metalloproteinase-9 (MMP-9) in kidney development and injury. Kidney Int. 68, 1963-1964.

Luaces, J.P., Rossi, L.F., Sciurano, R.B., Rebuzzini, P., Merico, V., Zuccotti, M., Merani, M. S., Garagna, S., 2014. Loss of Sertoli-germ cell adhesion determines the rapid germ cell elimination during the seasonal regression of the seminiferous epithelium of the large hairy armadillo Chaetophractus villosus. Biol. Reprod. 90, 1-11.

Matsumura, Y., Hisaki, K., Takaoka, M., Morimoto, S., 1990. Phosphoramidon, a metalloproteinase inhibitor, suppresses the hypertensive effect of big endothelin-1. Eur. J. Pharmacol. 185, 103-6.

Mazaud, S., Guyot, R., Guigon, C.J., Coudouel, N., Le Magueresse-Battistoni, B., Magre, S., 2005. Basal membrane remodeling during follicle histogenesis in the rat ovary: contribution of proteinases of the MMP and PA families. Dev. Biol. 277, 403-16.

McFarlane, L., Truong, V., Palmer, J.S., Wilhelm, D., 2013. Novel PCR assay for determining the genetic sex of mice. Sex. Dev. 7, 207-211.

McMahon, E.G., Palomo, M.A., Moore, W.M., 1991. Phosphoramidon blocks the pressor activity of big endothelin[1-39] and lowers blood pressure in spontaneously hypertensive rats. J. Cardiovasc. Pharmacol. 7, S29-33.

Nagano, R., Tabata, S., Nakanishi, Y., Ohsako, S., Kurohmaru, M., Hayashi, Y., 2000. Reproliferation and relocation of mouse male germ cells (gonocytes) during prespermatogenesis. Anat. Rec. 258, 210-220.

Nel-Themaat L., Vadakkan T.J., Wang Y., Dickinson M.E., Akiyama H., Behringer R.R., 2009. Morphometric analysis of testis cord formation in Sox9-EGFP mice. Dev. Dyn. 238, $1100-10$.

Nishino, K., Yamanouchi, K., Naito, K., Tojo, H., 2002. Matrix metalloproteinases regulate mesonephric cell migration in developing XY gonads which correlates with the inhibition of tissue inhibitor of metalloproteinase-3 by Sry. Dev. Growth. Differ. 44, 35-43.

Ota, K., Stetler-Stevenson, W.G., Yang, Q., Kumar, A., Wada, J., Kashihara, N., Wallner, E.I., Kanwar, Y.S., 1998. Cloning of murine membrane-type-1-matrix metalloproteinase (MT-1-MMP) and its metanephric developmental regulation with respect to MMP-2 and its inhibitor. Kidney Int. 54, 131-142.

Paranko, J., Pelliniemi, L.J., Vaheri, A., Foidart, J.M., Lakkala-Paranko, T., 1983. Morphogenesis and fibronectin in sexual differentiation of rat embryonic gonads. Differentiation 23 Suppl, S72-81. 
Pepling, M.E., Spradling, A.C., 2001. Mouse ovarian germ cell cysts undergo programmed breakdown to form primordial follicles. Dev. Biol. 234, 339-351.

Pepling, M.E., Sundman, E.A., Patterson, N.L., Gephardt, G.W., Medico, L., Wilson, K.I., 2010. Differences in oocyte development and estradiol sensitivity among mouse strains. Reprod. Camb. Engl. 139, 349-357.

Piprek, R.P., 2009a. Genetic mechanisms underlying male sex determination in mammals. J. Appl. Genet. 50, 347-360.

Piprek, R.P., 2009b. Molecular mechanisms underlying female sex determinationantagonism between female and male pathway. Folia Biol. (Krakow) 57, 105-113.

Piprek, R.P., 2010. Molecular machinery of gonadal differentiation in mammals. Int. J. Dev. Biol. 54, 779-786.

Piprek, R.P., Kloc, M., Kubiak, J.Z., 2016. Early Development of the Gonads: Origin and Differentiation of the Somatic Cells of the Genital Ridges. Results Probl. Cell Differ. 58, 122.

Piprek, R.P., Kloc, M., Tassan, J.P., Kubiak, J.Z., 2017b. Development of Xenopus laevis bipotential gonads into testis or ovary is driven by sex-specific cell-cell interactions, proliferation rate, cell migration and deposition of extracellular matrix. Dev. Biol. 432, 298310.

Piprek, R.P., Kolasa, M., Podkowa, D., Kloc, M., Kubiak, J.Z., 2017a. Cell adhesion molecules expression pattern indicates that somatic cells arbitrate gonadal sex of differentiating bipotential fetal mouse gonad. Mech. Dev. 147, 17-27.

Piprek, R.P., Kolasa, M., Podkowa, D., Kloc, M., Kubiak, J.Z., 2018. Transcriptional profiling validates involvement of extracellular matrix and proteinases genes in mouse gonad development. Mech. Dev. 149, 9-19.

Plumpton, C., Kalinka, S., Martin, R.C., Horton, J.K., Davenport, A.P., 1994. Effects of phosphoramidon and pepstatin A on the secretion of endothelin-1 and big endothelin-1 by human umbilical vein endothelial cells: measurement by two-site enzyme-linked immunosorbent assays. Clin. Sci. (Lond) 87, 245-51.

Rehman, A.A., Ahsan, H., Khan, F.H., 2013. $\alpha$-2-Macroglobulin: a physiological guardian. J. Cell. Physiol. 228, 1665-75.

Rosenfeldt, M.T., Valentino, M., Labruzzo, S., Scudder, L., Pavlaki, M., Cao, J., Vacirca, J., Bahou, W.F., Zucker, S., 2005. The organomercurial 4-aminophenylmercuric acetate, independent of matrix metalloproteinases, induces dose-dependent activation/inhibition of platelet aggregation. Thromb. Haemost. 93, 326-30.

Schmahl, J., Eicher, E.M., Washburn, L.L., Capel, B., 2000. Sry induces cell proliferation in the mouse gonad. Development 127, 65-73. 
560

561

562

563

564

565

566

567

568

569

570

571

572

573

574

575

576

577

578

579

580

581

582

583

584

585

586

587

588

589

590

591

592

593

594

595

596

597

598

599

Stamenkovic, I., 2003. Extracellular matrix remodelling: the role of matrix metalloproteinases. J. Pathol. 200, 448-64.

Svingen, T., Koopman, P., 2013. Building the mammalian testis: origins, differentiation, and assembly of the component cell populations. Genes Dev. 27, 2409-2426.

Tanney, D.C., Feng, L., Pollock, A.S., Lovett, D.H., 1998. Regulated expression of matrix metalloproteinases and TIMP in nephrogenesis. Dev. Dyn. 213, 121-129.

Tilmann, C., Capel, B., 1999. Mesonephric cell migration induces testis cord formation and Sertoli cell differentiation in the mammalian gonad. Development 126, 2883-90.

Westwood, M., Aplin, J.D., Collinge, I.A., Gill, A., White, A., Gibson, J.M., 2001. alpha 2Macroglobulin: a new component in the insulin-like growth factor/insulin-like growth factor binding protein-1 axis. J. Biol. Chem. 276, 41668-74.

Yao, H.H., DiNapoli, L., Capel, B., 2004. Cellular mechanisms of sex determination in the red-eared slider turtle, Trachemys scripta. Mech. Dev. 121, 1393-1401.

Yue, B., 2014. Biology of the extracellular matrix: an overview. J. Glaucoma. 23, S20-3.

(1)

3 
600

601

602

603

604

605

606

607

608

609

610

611

612

613

614

615

616

617

618

619

620

621

622

623

624

625

626

627

628

629

630

631

632

633

Figure legends

Fig. 1. Gelatin zymography of developing XY and XX mouse gonads cultured in vitro for 3 days. Zymography shows that phosphoramidon inhibits matrix-metalloproteinase 2, 3 and 9, (MMP2, MMP3, and MMP9) to a higher degree than $\alpha$-2-macroglobulin and leupeptin, and that APMA (4-aminophenylmercuric acetate) activates these three MMPs.

\section{Fig. 2. Development of mouse XY and XX gonads in vivo at E11.5 and E13.5. A. XY} undifferentiated gonad structure at E11.5. The somatic (arrows) and germ cells (arrowheads) are evenly distributed within the gonad. B. Testis at E13.5 developed in vivo. The testis cords (encircled) are present, the interstitium (i) is located between the testis cords, and the germ cells (arrowhead) are located within the cords. C. XX undifferentiated gonad at E11.5. The somatic (arrows) and germ cells (arrowheads) are evenly distributed within the gonad. D. Ovary at E13.5 developed in vivo. The ovigerous cords are small, irregular and not well differentiated. Scale bar is equal to $25 \mu \mathrm{m}$.

\section{Fig. 3. Effect of 3-day in vitro culture of XY gonads in the control and in the presence of} a-2-macroglobulin. A. Control XY gonad after 3-day in vitro culture in the absence of MMP inhibitors. The basement membranes (arrow) and the blue-stained ECM surrounding the testis cords (encircled) are visible. The germ cells (arrowhead) are present in the testis cords. B. XY gonad after 3-day in vitro culture in the presence of $\alpha$-2-macroglobulin. The amount of blue-stained ECM is slightly higher than in the control; the testis cords (encircled) and the germ cells (arrowheads) are present. The apoptotic cells are marked by the asterisks. C,D. Immunostaining of AMH (anti-müllerian hormone - a marker of Sertoli cells). The strongest signal is visible in the control gonads. E,F. Immunostaining of collagen I. There is an increase in collagen I accumulation between cells in gonads treated with $\alpha$-2-macroglobulin. $\mathbf{G}, \mathbf{H}$. Immunostaining of laminin. There is an increase of signal in gonads treated with $\alpha-2-$ macroglobulin. I,J. Immunostaining of caspase 3 (apoptosis marker). Only singular apoptotic cells are present. Scale bar is equal to $25 \mu \mathrm{m}$.

\section{Fig. 4. Effect of 3-day in vitro culture of XY gonads in the presence of leupeptin and} phosphoramidon. A. XY gonad after 3-day in vitro culture in the presence of leupeptin. There is high amount of ECM, the germ cells are absent. The testis cords (encircled) are small and sterile. Occasionally, the apoptotic cells (asterisk) are visible. B. XY gonad after 3-day in vitro culture with phosphoramidon. The is very high amount of ECM and the germ cells are 
634 absent. Because of the high amount of ECM all cells are dispersed and the testis cords do not

635 form. The apoptotic cells (asterisk) are present. C,D. Immunostaining of AMH. In the gonads 636 treated with MMP inhibitors, the stronger the inhibitor the weaker the AMH signal. E,F.

637 Immunostaining of collagen I. The gonads cultured in the presence of phosphoramidon had

638 the strongest collagen I signal. G,H. Immunostaining of laminin. The strongest signal is in the

639 gonads cultured in the presence of phosphoramidon. I,J. Immunostaining of caspase 3

640 (apoptosis marker). The most numerous apoptotic cells are present in the gonads cultured in 641 the presence of phosphoramidon. Scale bar is equal to $25 \mu \mathrm{m}$.

642

643 Fig. 5. Effect of 3-day in vitro culture of XX gonads in the control and in the presence of $644 \alpha$-2-macroglobulin. A. Control XX gonad after-3 day in vitro culture in the absence of MMP 645 inhibitors. The somatic and germ cells (arrowhead) are dispersed; blue-stained ECM is

646 present between groups of cells. B. XX gonad after 3-day in vitro culture in the presence of $\alpha$ 647 2-macroglobulin. The amount of blue-stained ECM is slightly higher than in the control.

648 Occasionally, the apoptotic cells (asterisk) are present. C,D. Immunostaining of collagen I.

649 There is increase in collagen I content between the cells in gonads treated with $\alpha-2$ -

650 macroglobulin. E,F. Immunostaining of laminin. There is increase in laminin content in the

651 gonads treated with $\alpha$-2-macroglobulin. G,H. Immunostaining of caspase 3 (apoptosis

652 marker). Only singular apoptotic cells are present. Scale bar is equal to $25 \mu \mathrm{m}$.

654 Fig. 6. Effect of 3-day in vitro culture of XX gonads in the presence of leupeptin and

655 phosphoramidon. A. XX gonad after 3-day in vitro culture in the presence of leupeptin. The 656 amount of ECM is higher; the germ cells are absent; occasionally, the apoptotic cells

657 (asterisk) are visible. B. XX gonad after 3day in vitro culture in the presence of 658 phosphoramidon. There is very high amount of ECM. The germ cells are absent. Because of 659 the high amount of ECM all cells are dispersed. The apoptotic cells (asterisk) are present.

660 C,D. Immunostaining of collagen I. The gonads cultured in the presence of phosphoramidon 661 have the strongest collagen I signal. E,F. Immunostaining of laminin. The gonads cultured in 662 the presence of phosphoramidon have the strongest laminin signal. G,H. Immunostaining of 663 caspase 3 (apoptosis marker). The most numerous apoptotic cells are present in the gonads 664 cultured in the presence of phosphoramidon. Scale bar is equal to $25 \mu \mathrm{m}$. 
In both XY (A) and XX (B) gonads, the cells are completely dispersed and only miniscule

668 amount of ECM is present between the cells. (C) There is no positive signal in gonads

669 immunostained for AMH. Scale bar is equal to $25 \mu \mathrm{m}$.

670

671 Fig. 8. Gene expression analysis after 3-day in vitro culture of XY and XX gonad in the 672 absence or presence of MMP inhibitors ( $\alpha$-2-macroglobulin, leupeptin,

673 phosphoramidon) and MMP activator (APMA). The expression of Oct4 ( marker of germ

674 cells), was lower in the gonads cultured with MMP inhibitors in comparison to the to the

675 control gonads and gonads cultured with APMA. The expression of testis-specific markers

676 (Sox9 and Amh) was slightly decreased in gonads cultured with MMP inhibitors, and

677 significantly decreased in gonads cultured with APMA. The expression of ovary-specific

678 follistatin (Fst) and control gene (Actb) show no significant changes in the gonads cultured

679 with MMP inhibitors or APMA. Relative quantitation (Y-axis) determines the changes in

680 steady-state mRNA level, data are normalized to the level of Actb expression (value $=1.0$ ).

681

682

683

684

685

686

687

688

689

690

691

692

693

694

695

696

697

698

699 
Table 1. Number of $X Y$ and $X X$ mouse fetuses used for the in vitro culture in the medium

supplemented with inhibitors/activator of metalloproteinases.

\begin{tabular}{|l|l|l|}
\hline Chemical reagent & $\begin{array}{l}\text { Number of } \\
\text { XY fetuses }\end{array}$ & $\begin{array}{l}\text { Number of } \\
\text { XX fetuses }\end{array}$ \\
\hline$\alpha$-2-macroglobulin & 14 & 16 \\
\hline Leupeptin & 20 & 15 \\
\hline Phosphoramidon & 17 & 21 \\
\hline APMA, 4-aminophenylmercuric acetate & 13 & 12 \\
\hline DMSO - control & 17 & 15 \\
\hline
\end{tabular}

Table 2. Inhibitors and activator of metalloproteinases used in the experiment.

\begin{tabular}{|l|l|l|l|}
\hline Chemical reagent & Action & Concentration & Product number \\
\hline $\boldsymbol{\alpha}$-2-macroglobulin & $\begin{array}{l}\text { an inhibitor of } \\
\text { endoproteases, including } \\
\text { metalloproteinases (Cawston } \\
\text { and Mercer, 1986) }\end{array}$ & $100 \mu \mathrm{g} / \mathrm{ml}$ & Sigma, M3398 \\
\hline $\begin{array}{l}\text { Leupeptin (N-acetyl- } \\
\text { L-leucyl-L-leucyl-L- } \\
\text { argininal) }\end{array}$ & $\begin{array}{l}\text { an inhibitor of } \\
\text { metalloproteinases, serine } \\
\text { and threonine proteases, } \\
\text { calpain, cathepsin, trypsin, } \\
\text { plasmin, papain (Kuramochi } \\
\text { et al., 1979) }\end{array}$ & $100 \mu \mathrm{M}$ & Sigma, L5793 \\
\hline Phosphoramidon & $\begin{array}{l}\text { a weak inhibitor of } \\
\text { metalloproteinases } \\
\text { (Kitagishi and Hiromi, 1984; } \\
\text { Matsumura et al., 1990) }\end{array}$ & $200 \mu \mathrm{M}$ & Sigma, R7385 \\
\hline $\begin{array}{l}\text { APMA (4- } \\
\text { aminophenylmercuric } \\
\text { acetate) }\end{array}$ & $\begin{array}{l}\text { an activator of } \\
\text { metalloproteinases (Galazka } \\
\text { et al., 1996) }\end{array}$ & $1.5 \mathrm{mM}$ & Sigma, A9563 \\
\hline
\end{tabular}


Table 3. Summary of the experimental results.

\begin{tabular}{|c|c|c|c|}
\hline Substance & $\begin{array}{c}\text { MMPs } \\
\text { activity in } \\
\text { zymography }\end{array}$ & Histology and IHC & Gene expression \\
\hline Control & $\begin{array}{l}\text { Activity } \\
\text { detected }\end{array}$ & $\begin{array}{l}\text { - Gonadal sex recognizable by } \\
\text { morphological features } \\
\text { - Testis cords present } \\
\text { - Germ cells present }\end{array}$ & $\begin{array}{l}\text { Oct4, Sox } 9, A m h \\
\text { and Fst expressed }\end{array}$ \\
\hline$\alpha-2$-macroglobulin & $\begin{array}{l}\text { Slightly } \\
\text { decreased }\end{array}$ & $\begin{array}{l}\text { Slightly increased ECM } \\
\text { accumulation } \\
\text { - Gonadal sex recognizable } \\
\text { - Testis cords present } \\
\text { - Germ cells present } \\
\text { - Apoptosis }\end{array}$ & \multirow[t]{3}{*}{$\begin{array}{l}\text { Lower } \\
\text { Oct4 expression }\end{array}$} \\
\hline Leupeptin & Decreased & $\begin{array}{l}\text { Increased ECM accumulation } \\
\text { - Gonadal sex recognizable } \\
\text { - Testis cords present } \\
\text { - Germ cells absence } \\
\text { - Apoptosis }\end{array}$ & \\
\hline Phosphoramidon & $\begin{array}{l}\text { The strongest } \\
\text { decrease }\end{array}$ & $\begin{array}{l}\text { High structure impairment by } \\
\text { strong ECM accumulation } \\
\text { - Gonadal sex unrecognizable } \\
\text { by morphological features } \\
\text { - Cells dispersed in ECM } \\
\text { - No testis cords } \\
\text { - Germ cells absence } \\
\text { - Apoptosis }\end{array}$ & \\
\hline APMA & High activity & $\begin{array}{l}\text { High structure disturbance by } \\
\text { strong ECM dispersion } \\
\text { - Gonadal sex unrecognizable } \\
\text { by morphological features } \\
\text { - No testis cords } \\
\text { - Cells dispersed }\end{array}$ & $\begin{array}{l}\text { Lower } \\
\text { Sox9 and Amh } \\
\text { expression }\end{array}$ \\
\hline
\end{tabular}

Table 4. Mean number and standard deviation of apoptotic (caspase 3-positive) cells per $10,000 \mu \mathrm{m}^{2}$ in $\mathrm{XY}$ and $\mathrm{XX}$ gonads after 3 days of in vitro culture.

\begin{tabular}{|l|c|c|}
\hline Inhibitor & \multicolumn{1}{|c|}{ XY } & XX \\
\hline $\begin{array}{l}\text { Control without } \\
\text { inhibitor }\end{array}$ & $0.3+/-0.48^{\mathrm{a}}$ & $0.4+/-0.7^{\mathrm{a}}$ \\
\hline $\boldsymbol{\alpha - 2 - m a c r o g l o b u l i n}$ & $1.1+/-1.1^{\mathrm{a}}$ & $1.2+/-1.32^{\mathrm{a}}$ \\
\hline Leupeptin & $2.1+/-1.73^{\mathrm{a}}$ & $2.4+/-1.71^{\mathrm{a}}$ \\
\hline Phosphoramidon & $6.4+/-2.72^{\mathrm{a}}$ & $5.7+/-2.54^{\mathrm{a}}$ \\
\hline
\end{tabular}


$723{ }^{a}$ Significant difference between the experimental and control gonads $\left(\chi^{2}\right.$ test, $\left.\mathrm{P}<0.05\right)$.

Suppl. Table 1. Primers used for genotyping and RT-qPCR.

726

\begin{tabular}{|c|c|}
\hline Gene & Primers \\
\hline \multicolumn{2}{|c|}{ Primers used for genotyping } \\
\hline$S X$ (sex genotyping) & $\begin{array}{l}\text { F: GATGATTTGAGTGGAAATGTGAGGTA } \\
\text { R: CTTATGTTTATAGGCATGCACCATGTA }\end{array}$ \\
\hline \multicolumn{2}{|c|}{ Primers used for RT-qPCR } \\
\hline Oct4 & $\begin{array}{l}\text { F: GCATTCAAACTGAGGCACCA } \\
\text { R: AGCTTCTTTCCCCATCCCA }\end{array}$ \\
\hline Sox9 & $\begin{array}{l}\text { F: GTGCAAGCTGGCAAAGTTGA } \\
\text { R: TGCTCAGTTCACCGATGTCC }\end{array}$ \\
\hline Amh & $\begin{array}{l}\text { F: TCAACCAAGCAGAGAAGGTG } \\
\text { R: AGTCATCCGCGTGAAACAG }\end{array}$ \\
\hline Fst & $\begin{array}{l}\text { F: AAAACCTACCGCAACGAATG } \\
\text { R: TTCAGAAGAGGAGGGCTCTG }\end{array}$ \\
\hline$A c t b$ & $\begin{array}{l}\text { F: CATGTACGTTGCTATCCAGGC } \\
\text { R: CTCCTTAATGTCACGCACGAT }\end{array}$ \\
\hline
\end{tabular}


Fig. 1.

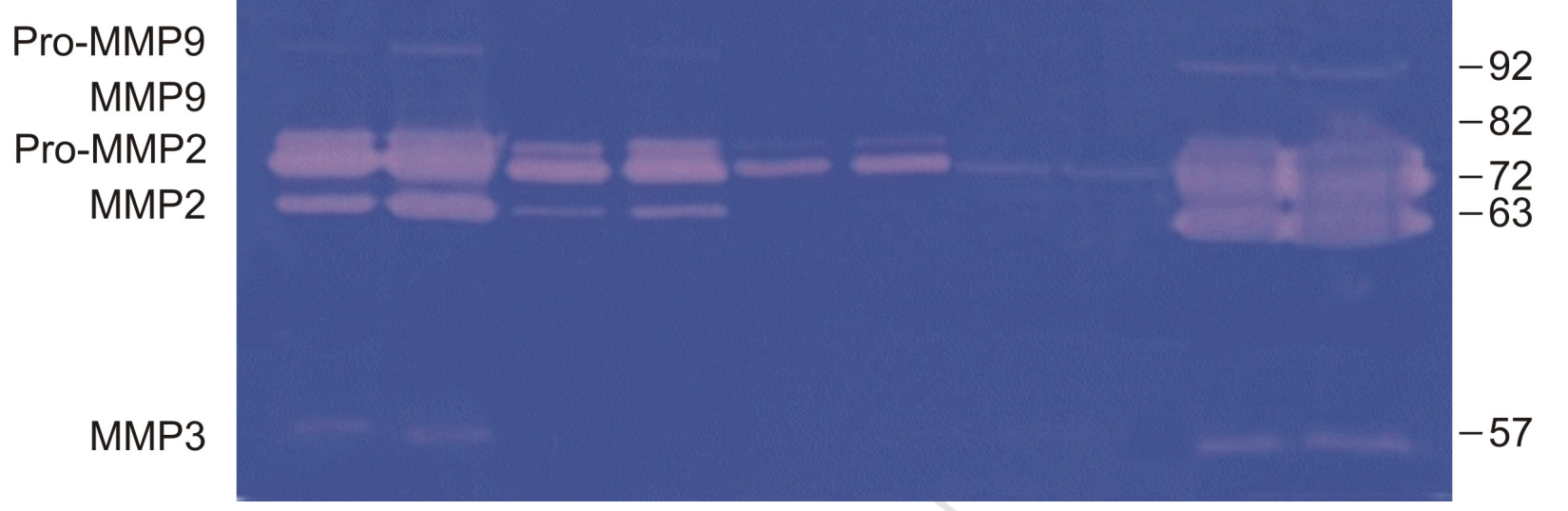


Fig. 2.

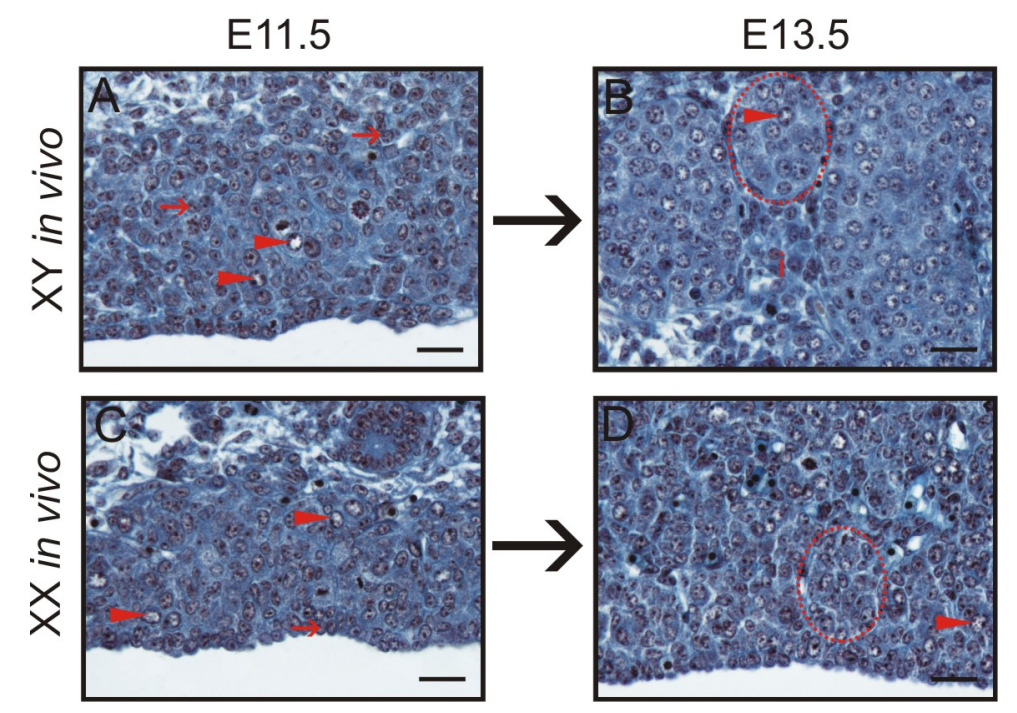


Fig. 3.
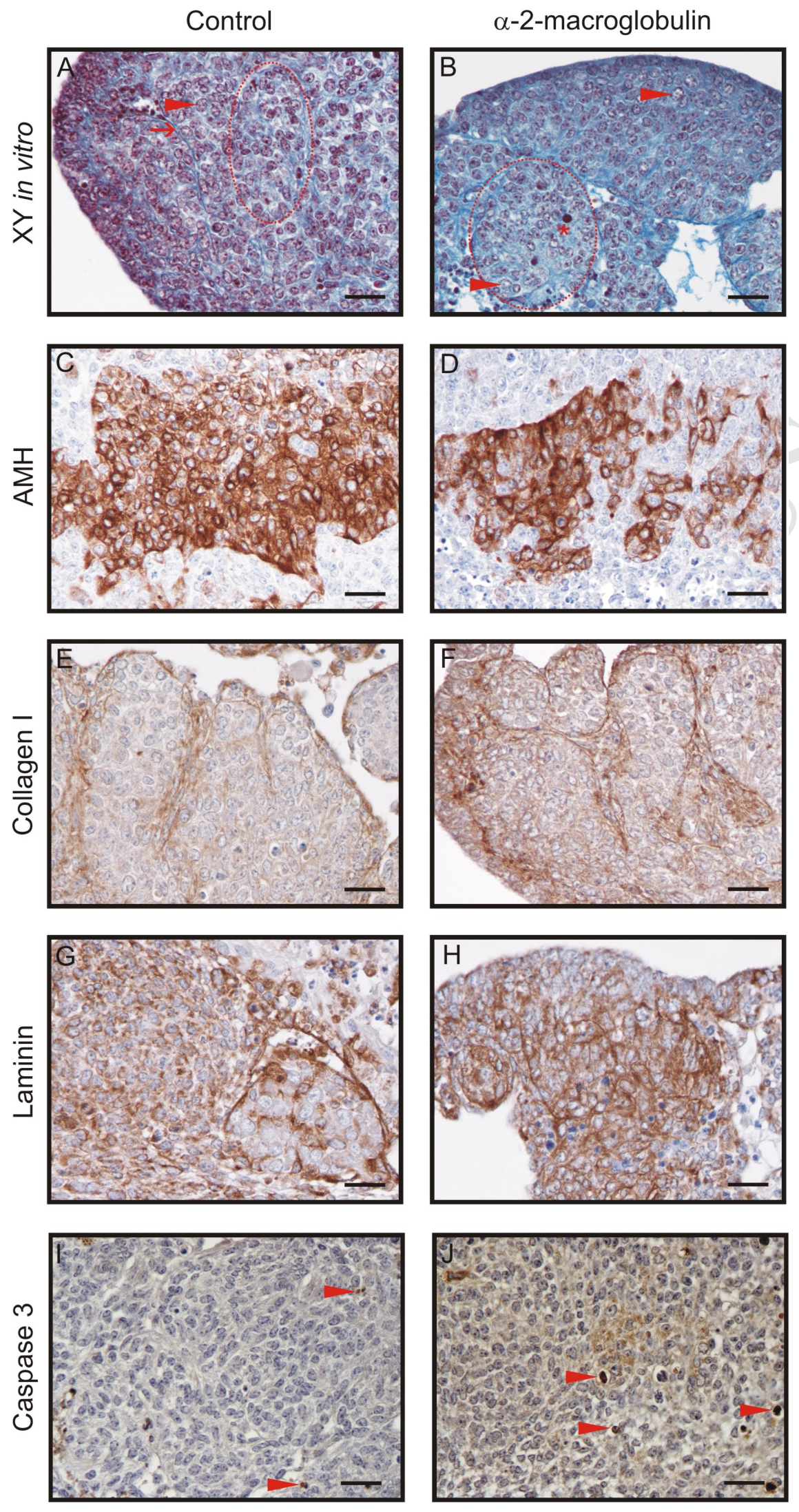
Fig. 4.
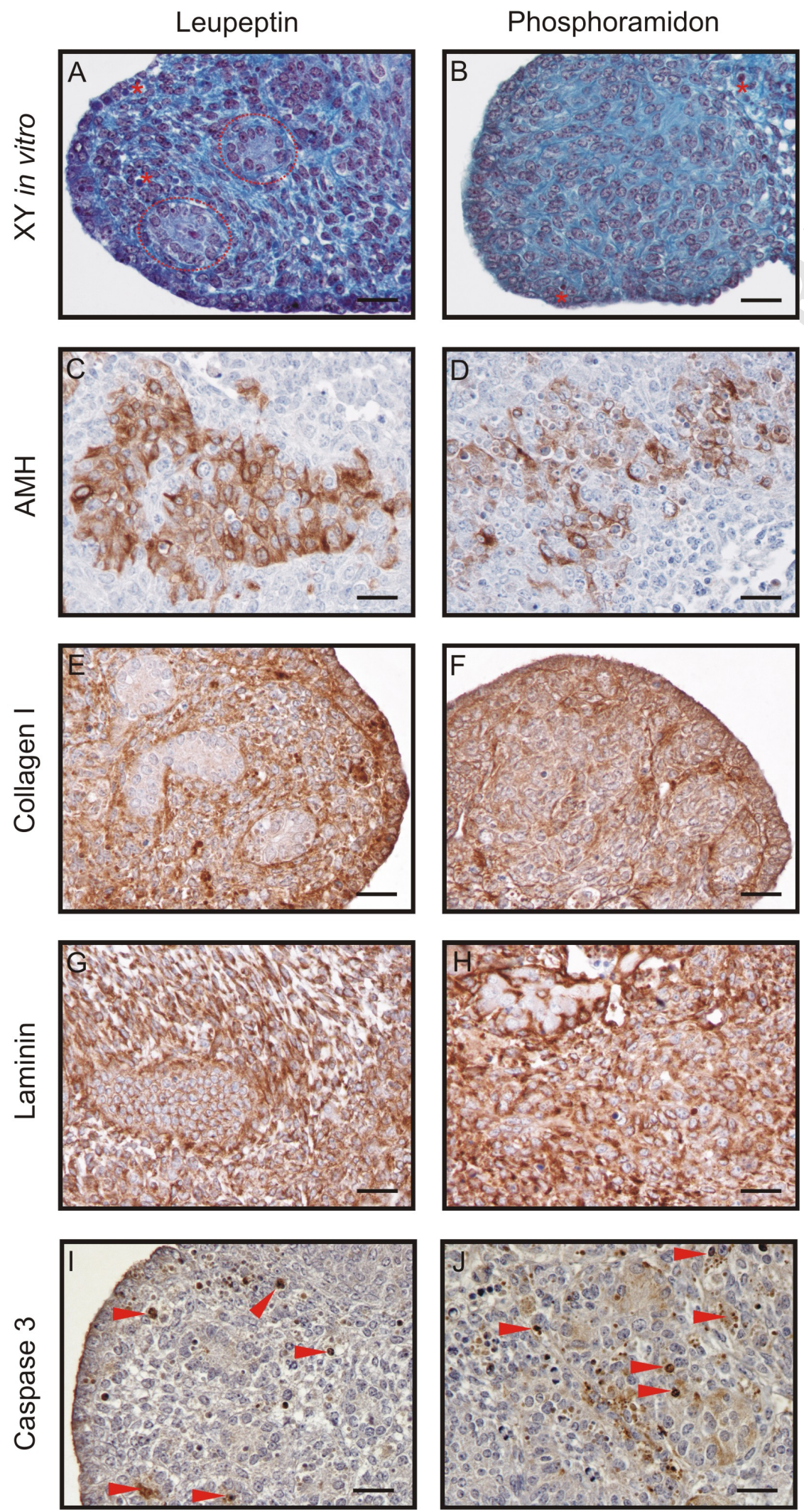
Fig. 5.
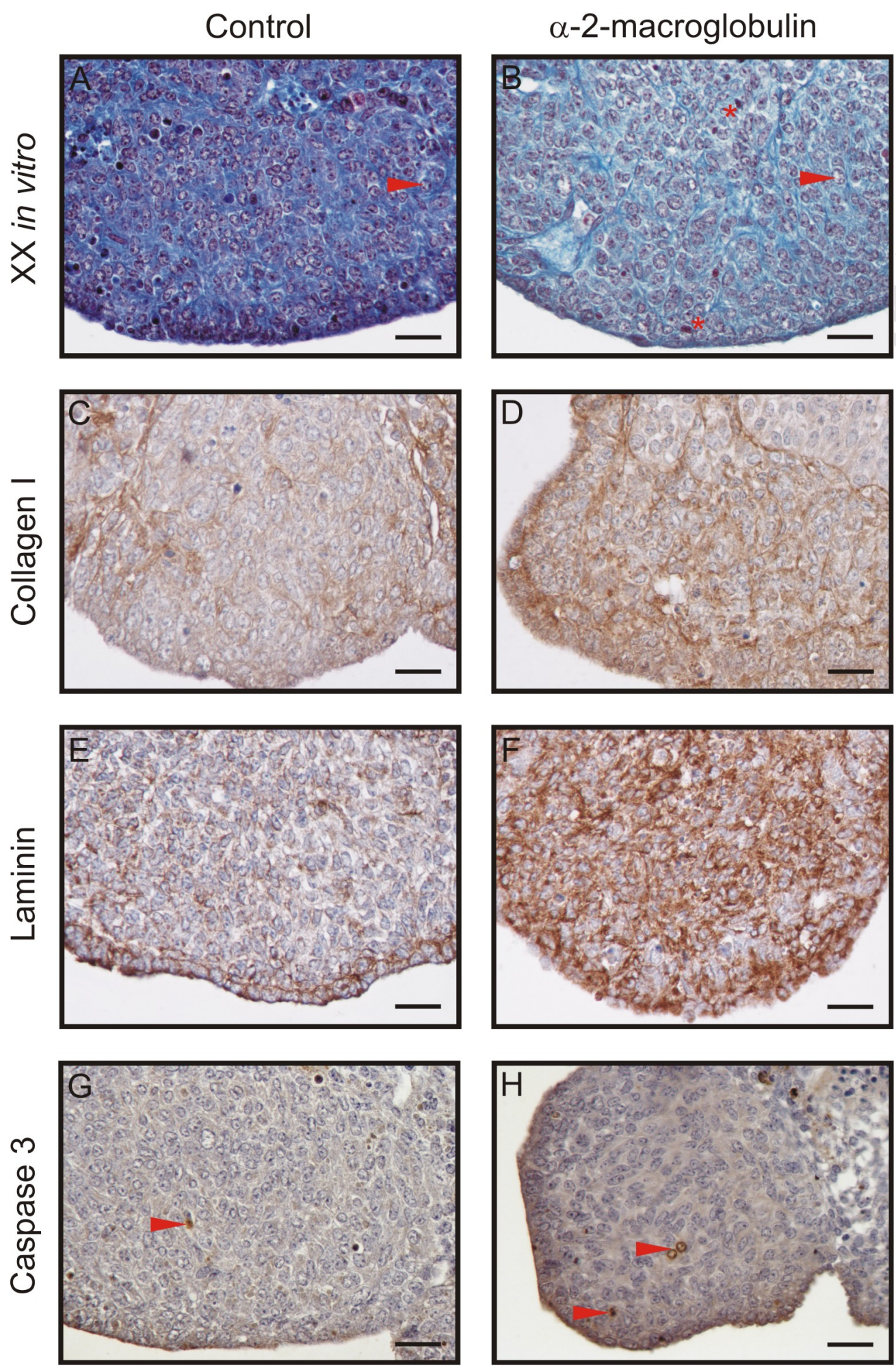
Fig. 6.
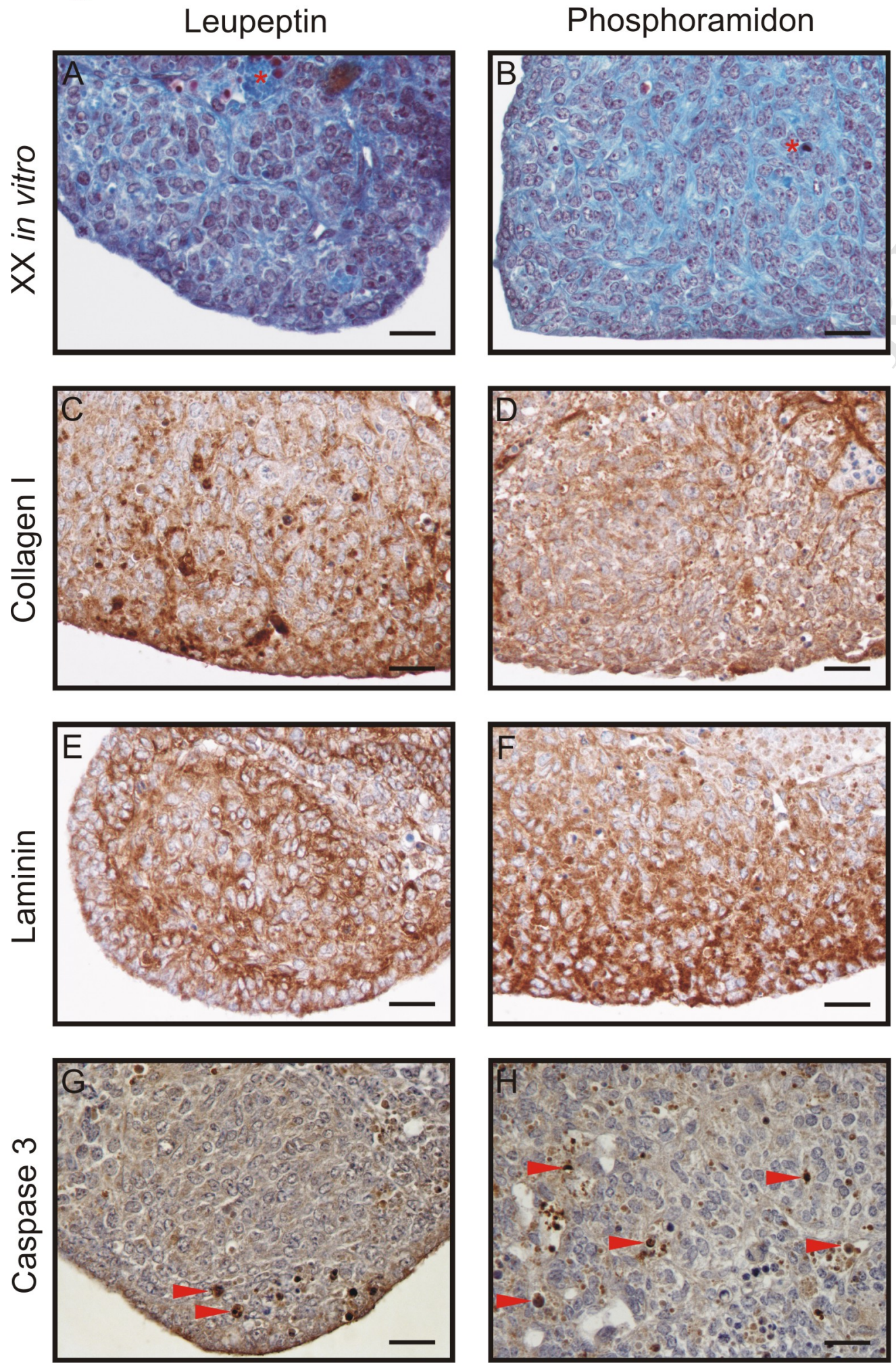
Fig. 7.
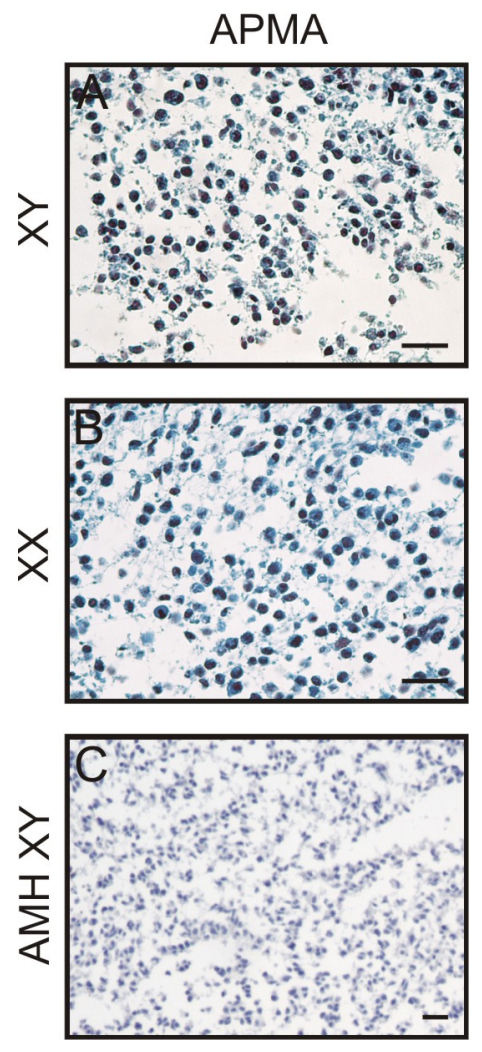
$X Y$
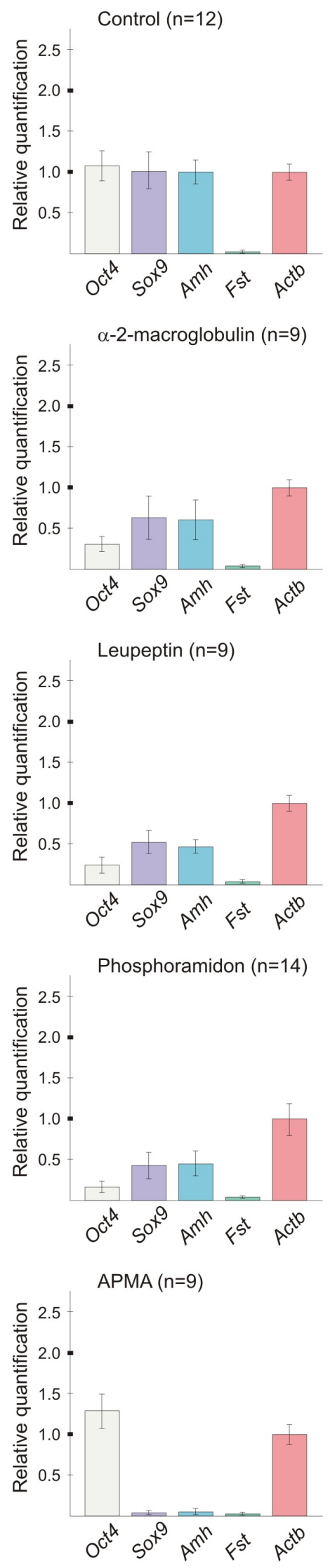

XX
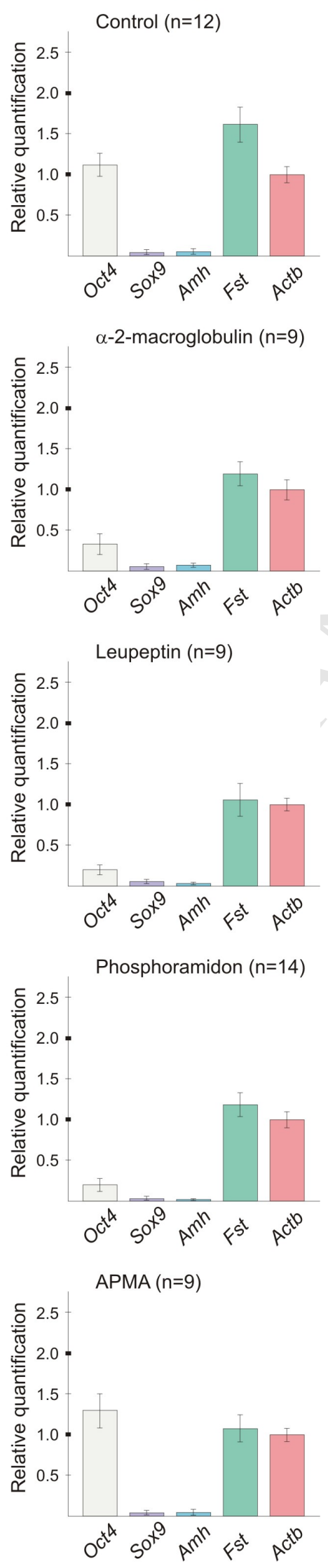